\title{
Phytoplankton and Bacterial Communities in South Harbour, Manila Bay, Philippines
}

\author{
Rhodora V. Azanza ${ }^{1,2^{*}}$, Nero M. Austero ${ }^{1}$, Jenelle Clarisse R. Dungca ${ }^{1}$, Frenchly Joyce O. Caspe ${ }^{1}$, and Lidita \\ Khandeparker ${ }^{3}$ \\ ${ }^{1}$ The Marine Science Institute, University of the Philippines, Diliman, Quezon City 1101 Philippines \\ ${ }^{2}$ National Academy of Science and Technology, DOST Complex, Bicutan, Taguig City, 1631 Philippines \\ ${ }^{3}$ Council of Scientific and Industrial Research (CSIR), National Institute of Oceanography, Goa, India \\ *Corresponding author: rvazanza@up.edu.ph
}

\author{
KEYWORDS \\ Bacteria \\ Harmful algal bloom \\ Manila \\ Phytoplankton \\ South Harbour
}

\begin{abstract}
In line with the ASEAN-India project "Extent of Transfer of Alien Invasive Organisms in South/Southeast Asia via Shipping", phytoplankton and bacterial communities in the waters off South Harbour, Manila Bay were investigated. Sampling was done in July and August 2012 and in April and May 2013. A total of 67 phytoplankton species including 29 diatoms and 38 dinoflagellates were identified. Potentially toxic Pseudo-nitzschia spp. were among the diatoms found as well as dinoflagellates Alexandrium spp., and Gymnodinium spp. The diatom Skeletonema costatum appeared to be the dominant species in July and August 2012, whereas Chaetoceros spp. constituted over $85 \%$ of the total phytoplankton assemblage in April and May 2013. Mean bacterial abundance ranged from $9.53 \times 10^{2}-3.18 \times 10^{5}$ cells $/ \mathrm{mL}$ in July 2012. In addition, 93 bacterial isolates were identified using $16 \mathrm{~S}$ rDNA, several of which belonged to the following phyla: Actinobacteria, Bacteriodetes, Firmicutes, and Proteobacteria; whereas, others were determined as uncultured bacterial clones. These results will serve as a valuable baseline for future studies on phytoplankton and bacterial community structure in Manila Bay.
\end{abstract}

(c) The Author(s) 2018. This article is distributed under a Creative Commons Attribution-ShareAlike 4.0 International license.

\section{INTRODUCTION}

Among the major ports in the Philippines, South Harbour in Manila Bay has catered to over 1500 foreign and over 5000 domestic vessels from year 2000 to 2012 (Philippine Ports Authority 2015) indicating high vessel traffic. Since cargo and other shipping vessels carry thousands of potentially harmful organisms and bacteria, the process of ballast water exchange present high risks of introduction and transport of these species from port to port and from region to region (Drake et al. 2007; Altug et al. 2012). In addition, the issues on alien invasive species that have been long implicated with ballast water movement need further assessment on the native species and potentially introduced species present in the receiving regions (Smayda 2007).

Recent studies regarding port water surveys have focused on the risks and hazards of transfer of Harmful Algal Blooms (HABs), pathogenic bacteria/viruses, and alien biota from one region to another (e.g., Rao and Mohanchand 1988; Varela and Prego 2003; Webber et al. 2003; Zamora-Ley et al. 2006; Ho et al. 2008; Chandrasekera and Fernando 2009). In the A Coruña Harbour (northwestern Spain) for example, high biomass of large diatom dominated blooms was observed, indicative of eutrophication (Varela and Prego, 2003). The high risks of transfer of HAB species into other regions pose threats to all receiving areas wherein highly adaptive, introduced species successfully establish populations and outcompete native species (Butron et al. 2011).

Despite studies on surveys of Manila Bay regarding recurrent HABs and eutrophication (Azanza et al. 2004; Hansen et al. 2004; Chang et al. 2009), there has been no assessment conducted on phytoplankton and bacterial assemblages in major ports of the country. Therefore, as part of the ASEAN-India project "Extent of Transfer of Alien Invasive Organisms in South/Southeast Asia via Shipping", this paper presents the baseline information on microalgae and bacteria necessary for identifying potentially toxic and harmful/pathogenic species already been present in the coastal waters of South Harbour, Manila Bay.

\section{MATERIALS AND METHODS}

\subsection{Study area}

South Harbour is located at the northeast shoulder of Manila Bay $\left(14^{\circ} 36.2^{\prime} \mathrm{N}, 120^{\circ} 58.0^{\prime} \mathrm{E}\right)$ approximately $45 \mathrm{~km}$ from the estuary of Pasig River. It has a shoreline protected by a $3 \mathrm{~km}$ long rock breakwater enclosing about 600 hectares of anchorage including 5 piers, namely Pier 15, 13, 9, 6 and 3 (Philippine Ports Authority 2015). Six designated stations (Station 1: Pier 15, Station 2: Pier 13, Station 3: Pier 9, Station 4: Pier 5, Station 5: Engineering Island, and Station 6) along the harbour's pier facilities were sampled during the field surveys in 2012 (July 6 and August 8) and in 2013 (April 10 and May 10) (Figure 1).

\subsection{Phytoplankton analysis}

To determine the abundance and composition of phytoplankton in South Harbour, $1 \mathrm{~L}$ water samples were collected at near surface ( $1 \mathrm{~m}$ below the surface) using a $5 \mathrm{~L}$ Niskin water sampler. Subsequently, samples were preserved with Lugol's solution and used for qualitative analysis. Enumeration and counting of phytoplankton 


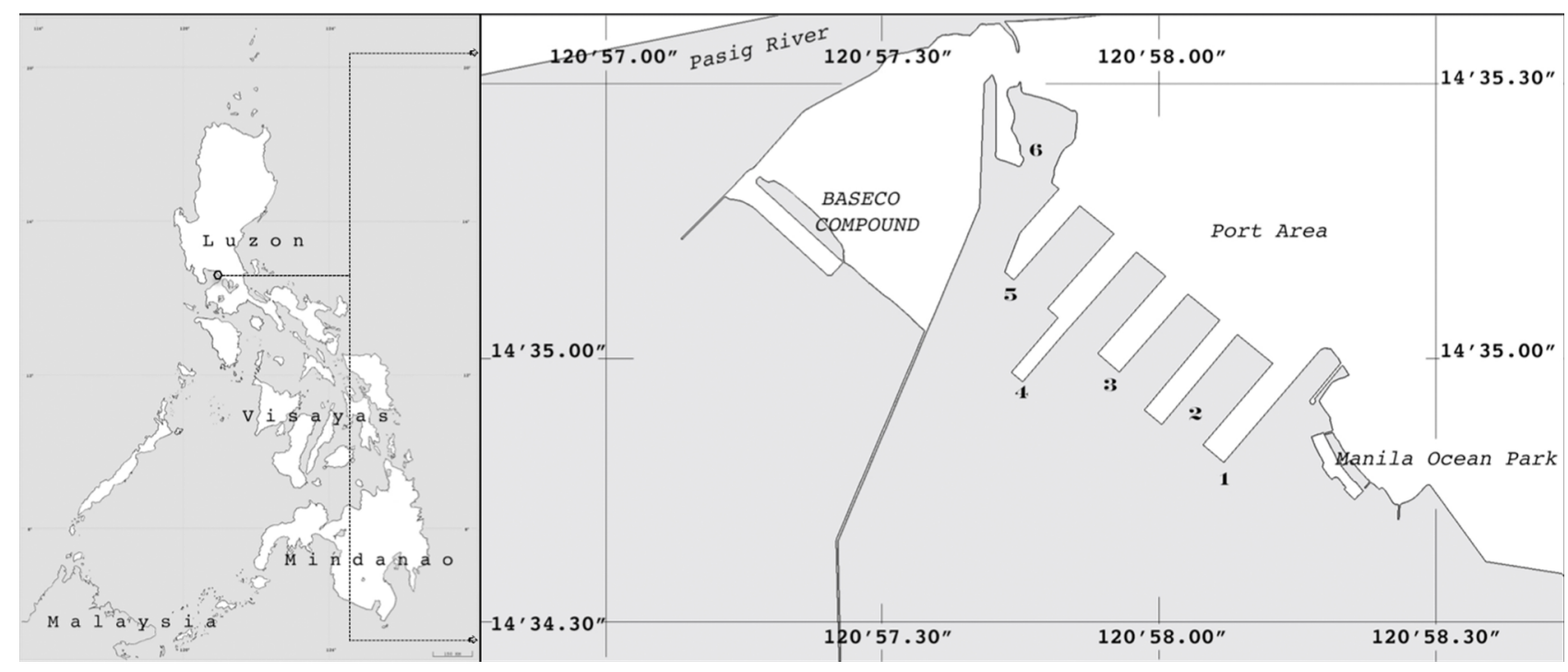

Figure 1. Established sampling stations in South Harbour, Manila Bay, Luzon, The Philippines (Map Source: Re-drawn from Google Earth Pro and Google Maps).

was done using Sedgewick-Rafter counting chamber based on microscopic and molecular methods for quantitative phytoplankton analysis following the technique of Azanza (1997) and Corrales et al. (1995). Phytoplankton species were identified to the lowest taxonomic level possible using Tomas (1997) and Yamaji (1984).

\subsection{Total bacterial abundance}

Water samples collected in July 2012 were analyzed for total bacterial count. Five-milliliter $(5 \mathrm{~mL})$ seawater samples from each station were fixed with $250 \mu \mathrm{L}$ formalin and were filtered through $0.22 \mu \mathrm{m}$ syringe filter (Whatman $^{\mathrm{TM}}$, PURADISC ${ }^{\mathrm{TM}} 25$ NYL Disposable Filter Device with $0.22 \mu \mathrm{m}$ Nylon Membrane with $25 \mathrm{~mm}$ diameter polypropylene housing). Fixed samples were analyzed at the Council of Scientific and Industrial Research (CSIR), National Institute of Oceanography (NIO) in Goa, India. Total bacterial count was determined using flow cytometry. Briefly, the samples were stained with SYBR Green I at 1:10,000 final concentrations (Marie et al. 1996) and incubated for $15 \mathrm{~min}$ in the dark at room temperature. After incubation, samples were analyzed using a BD FACSAria ${ }^{\mathrm{TM}}$ II flow cytometer equipped with a nuclear blue laser 488 $\mathrm{nm}$, which can differentiate green fluorescence excited by blue light. Emitted light was collected through following filters sets 488/10 band pass (BP) for right angle light scatter (SSC) and 530/30 band pass (BP) for green fluorescence. Fluorescent beads (1 $\mu \mathrm{m}$, Polysciences) were used as internal standards. Gating was done against SSC versus green fluorescence. Flow cytometry data were processed using BD FACSDIVA software.

One-liter water samples were collected in sterilized Nalgene bottles at near surface ( $1 \mathrm{~m}$ below the surface) and near-bottom ( $1 \mathrm{~m}$ above the seafloor) in stations deeper than $10 \mathrm{~m}$ using a $5 \mathrm{~L}$ Niskin water sampler. Twenty microliters $(20 \mu \mathrm{L})$ of water from the Nalgene bottles were spread plated in prepared Marine Agar (MA; Pronadisa, Spain). The inoculated plates were inverted and incubated at $24 \pm 2^{\circ} \mathrm{C}$ in the dark at the Harmful Algal Bloom Laboratory, The Marine Science Institute, University of the Philippines, Diliman, Quezon City. Growth of the bacteria was observed for one week. The colonies were separated and purified through subsequent streaking/transferring into prepared MA plates.

\subsection{Genetic identification of bacterial isolates}

The bacterial isolates were genetically identified via amplifying and sequencing their $16 \mathrm{~S}$ rDNA genes. DNA from bacterial culture broths was extracted using ZR Fungal/Bacterial DNA Mini Prep (Zymo Research ${ }^{\mathrm{TM}}$ ) following the instructions of the manufacturer. Amplification was done using these $16 \mathrm{~s}$ rDNA primers: $27 \mathrm{~F}$ (5'-AGAGTTTGATCCTGGCTCAG-3') and 534R (5'-ATTACCGCGGCTGCTGG-3'). Amplicons were then sent to First Base (Malaysia) for single pass reaction sequencing. The generated sequences were then compared by searching the nucleotide (nt) database of the National Center for Biotechnology Information (NCBI) using the nucleotide-to-nucleotide Basic Local Alignment Search Tool (BLASTN) (Altschul et al. 1990).

\section{RESULTS}

\subsection{Phytoplankton assemblage and composition}

Comprising a big fraction of the total phytoplankton assemblage, diatoms showed relative abundance of more than $98 \%$ cover in July and August 2012, and over 95\% in April and May 2013 in South Harbour Manila (Figure 2). Skeletonema costatum comprised $90 \%$ of the total phytoplankton assemblage in July and August 2012; whereas, Chaetoceros spp. constituted over $85 \%$ among all stations on April and May 2013.

Further, a total of 67 phytoplankton species including 29 diatoms and 38 dinoflagellates were recorded during the length of study (Table 1). Potentially harmful diatoms such as Chaetoceros spp., Pseudo-nitzschia spp., Skeletonema tropicum, and Thalassiosira spp., and potentially harmful dinoflagellates such as Akashiwo sanguineum, Alexandrium spp., Ceratium furca, Ceratium fusus, Dinophysis caudata, Dinophysis miles, Gymnodinium spp., Noctiluca scintillans, Prorocentrum micans, Prorocentrum rhathymum, and Prorocentrum sigmoides were also observed.

\subsection{Bacterial abundance and identification}

Mean bacterial abundance in July 2012 ranged from $9.53 \mathrm{x}$ $10^{2}-3.20 \times 10^{4}$ cells $/ \mathrm{mL}$ and $3.30 \times 10^{3}-3.18 \times 10^{5}$ cells $/ \mathrm{mL}$ in surface and bottom waters, respectively (Figure 3). In 
Table 1. List of potentially harmful algal bloom (HAB) causing taxa and other phytoplankton recorded from South Harbour, Manila Bay Philippines in 2012 (July 6 and August 8) and 2013 (April 10 and May 10). (-) absent, (+) present, $(++)$ abundant, $\left(^{*}\right)$ potentially invasive microalgae.

\begin{tabular}{|c|c|c|c|c|}
\hline \multirow[t]{2}{*}{ Taxa } & \multicolumn{2}{|c|}{2012} & \multicolumn{2}{|c|}{2013} \\
\hline & July & August & April & May \\
\hline \multicolumn{5}{|l|}{ Bacillariophyceae } \\
\hline Bacteriastrum spp. & - & - & + & + \\
\hline Ceratulina spp. & + & - & + & + \\
\hline Chaetoceros spp.* & + & - & ++ & ++ \\
\hline Cocconeis spp. & + & - & + & - \\
\hline Coscinodiscus spp.* & + & + & + & + \\
\hline Cylindrotheca spp. & + & - & + & - \\
\hline Cymbella spp. & - & - & + & - \\
\hline Favella spp. & - & - & + & - \\
\hline Guinardia spp. & - & - & + & + \\
\hline Guinardia striata & - & - & + & - \\
\hline Helicotheca spp. & - & - & + & + \\
\hline Hemiaulus spp. & - & - & + & - \\
\hline Licmophora spp. & - & + & + & - \\
\hline Milosira spp. & - & - & + & - \\
\hline Navicula spp. & + & - & + & + \\
\hline Nitzschia spp. & - & - & + & + \\
\hline Odontella aurita & - & - & + & + \\
\hline Odontella longicruris & - & - & + & + \\
\hline Odontella mobiliensis & - & - & + & + \\
\hline Odontella spp. & + & - & - & - \\
\hline Pleurosigma spp. & + & + & + & + \\
\hline Pseudo-nitszchia spp.* & ++ & + & + & - \\
\hline Rhizosolenia spp. & + & + & + & + \\
\hline Skeletonema costatum* & ++ & ++ & + & + \\
\hline Skeletonema tropicum & + & + & + & - \\
\hline Surreriella spp. & - & - & + & + \\
\hline Thallasionema spp. & + & - & + & - \\
\hline Thalassiosira spp.* & + & + & + & ++ \\
\hline Tintinnopsis spp. & + & - & + & + \\
\hline \multicolumn{5}{|l|}{ Dinophyceae } \\
\hline Akashiwo sanguineum * & + & - & + & + \\
\hline Alexandrium spp.* & + & - & + & + \\
\hline Ceratium spp. & + & - & + & - \\
\hline
\end{tabular}

Table 1. (continued) List of potentially harmful algal bloom (HAB) causing taxa and other phytoplankton recorded from South Harbour, Manila Bay Philippines in 2012 (July 6 and August 8) and 2013 (April 10 and May 10). $(-)$ absent, (+) present, $(++)$ abundant, $\left(^{*}\right)$ potentially invasive microalgae.

\begin{tabular}{lllll}
\hline Taxa & \multicolumn{2}{c}{2012} & \multicolumn{2}{c}{2013} \\
\cline { 2 - 4 } & July & August & April & May \\
\hline
\end{tabular}

\section{Dinophyceae}

Ceratium gravidum

Ceratium furca*

Ceratium fusus*

Ceratium macroceros

Ceratium praelongum

Dinophysis caudata*

Dinophysis miles*

Diplopsalis spp.

Gonyaulax spp.

Gonyaulax polygramma

Gonyaulax scrippsea

Gonyaulax spinifera

Gymnodinium spp.*

Gyrodinium spp.

Noctiluca scintillans*

Oxyphysis spp.

Peridinium spp.

Phalacroma spp.

Podolampas spp.

Prorocentrum spp.

Prorocentrum micans*

Prorocentrum rhathymum*

Prorocentrum sigmoides*

Protoperidinium spp.

Protoperidinium conicum

Protoperidinium divergens

Protoperidinium elegans

Protoperidinium oceanicum

Protoperidinium oblongatum

Protoperidinium pallidum

Protoperidinium pellucidum

Protoperidinium pentagonium

Pyrophacus spp.

Scrippsiella spp.

Scrippsiella trochoidea*

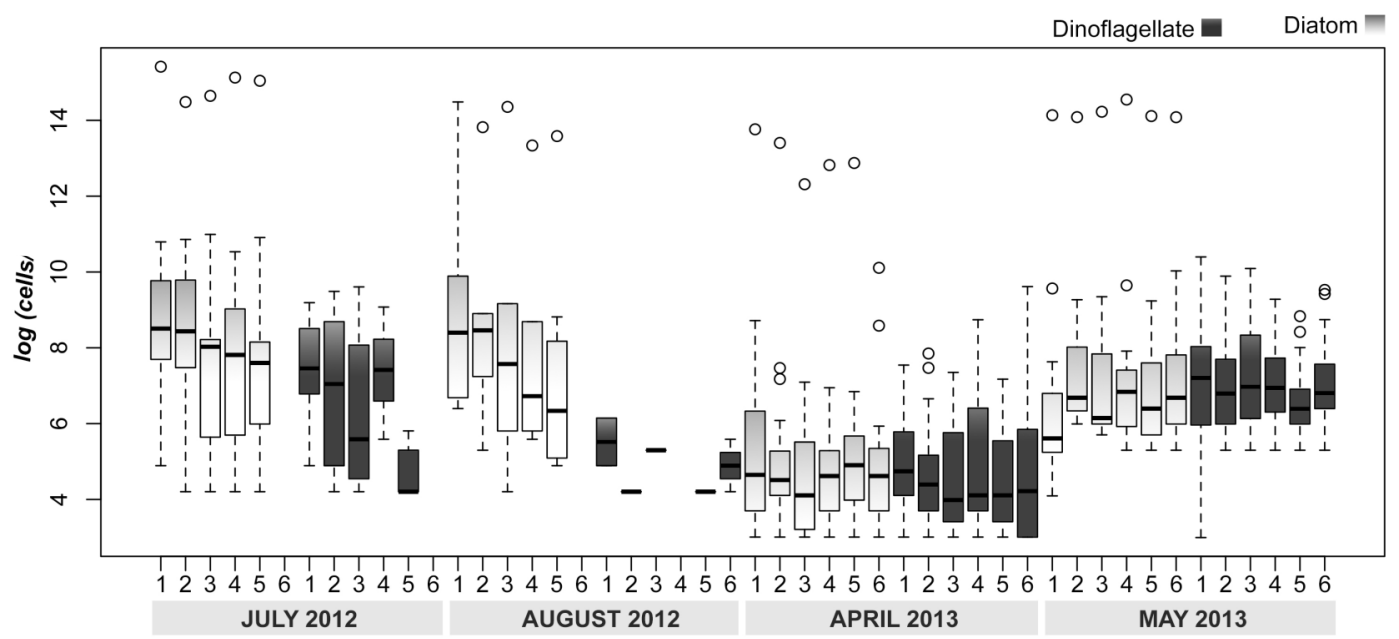

Figure 2. comparative logged abundance of diatoms and dinoflagellates sampled at six stations (1-6) in South Harbour Manila in 2012 (July 6 and August 8) and 2013 (April 10 and May 10). Note: Open circles represent values/abundance above 75\% quantiles or most specifically represent bloom forming taxa. 
Table 2. List of bacterial species from six stations along South Harbour, Manila Bay, Philippines in August 2012 using 16S rDNA identification. Note: (-) absent, $(+)$ present equivalent to 1 isolate, $\left(^{*}\right)$ reported human pathogen, same colored signs - one isolate has the same percent similarity (considering same length of base pairs) for two bacterial species.

\begin{tabular}{|c|c|c|c|c|c|c|}
\hline \multirow[t]{2}{*}{ Taxa } & \multicolumn{6}{|c|}{ Station } \\
\hline & 1 & 2 & 3 & 4 & 5 & 6 \\
\hline \multicolumn{7}{|l|}{ Surface water samples } \\
\hline \multicolumn{7}{|l|}{ Phylum Actinobacteria } \\
\hline Brachybacterium sp. H164 & - & - & - & - & - & +++ \\
\hline Brevibacterium sp. MN3-3 & - & - & + & - & - & - \\
\hline Dermacoccaceae bacterium 39 & - & + & - & - & - & - \\
\hline Gordonia bronchialis DSM 43247* & - & + & - & - & - & - \\
\hline Kytococcus sedentarius DSM 20547* & + & - & - & - & - & - \\
\hline Leucobacter sp. clone B2-9 & - & - & - & - & + & + \\
\hline Microbacterium sp. 5 & - & + & - & - & - & - \\
\hline Microbacterium oleivorans strain ANA47* & - & + & - & - & - & - \\
\hline Mycobacterium sp. CNJ823 PL04 & - & - & - & - & + & + \\
\hline Serinococcus sp. CNJ927 PL04 & - & - & - & - & - & + \\
\hline \multicolumn{7}{|l|}{ Phylum Bacteriodetes } \\
\hline Maribacter sp. B1 & - & - & - & - & + & - \\
\hline \multicolumn{7}{|l|}{ Phylum Firmicutes } \\
\hline Virgibacillus sp. A355 & - & + & - & - & - & - \\
\hline Virgibacillus marismortui strain 123 & - & - & + & - & + & - \\
\hline Virgibacillus olivae strain M2-39 & - & - & - & - & - & + \\
\hline Virgibacillus salarius strain SA-Vb1 & - & - & + & + & + & + \\
\hline \multicolumn{7}{|l|}{ Phylum Proteobacteria } \\
\hline Aurantimonas sp. & + & - & - & - & - & - \\
\hline Altererythrobacter sp. JL1452 & + & - & - & - & - & - \\
\hline Erythrobacter sp. 1LE25 & + & - & - & - & - & - \\
\hline Erythrobacter sp. AS- 45 & - & + & - & - & - & + \\
\hline Erythrobacter sp. CAR-8007 & + & - & - & - & - & + \\
\hline Erythrobacter sp. $\mathrm{H} 204$ & - & - & - & - & - & + \\
\hline Erythrobacter sp. UST081027-248 & - & - & - & + & - & - \\
\hline Erythrobacter litoralis HTCC2594 & - & - & - & + & - & - \\
\hline Hyphomonas taiwanensis strain HYP1 & - & - & - & - & + & - \\
\hline Mesorhizobium sp. G2DM-29 & + & - & - & - & - & - \\
\hline Paracoccus yeeistrain FD3 & + & - & - & - & - & - \\
\hline Pelagibaca sp. 2PR57-11 & - & + & - & - & - & - \\
\hline Pelagibacterium halotolerans B2 & - & - & - & + & - & - \\
\hline Rhodobacterales bacterium CB1079 & + & - & - & - & - & - \\
\hline Rhodobacter sp. 20V17 & + & + & - & - & - & - \\
\hline Ruegeria atlantica strain SS-05 & - & - & - & + & - & - \\
\hline Ruegeria lacuscaerulensis strain F75197 & - & - & - & ++ & - & - \\
\hline $\begin{array}{l}\text { Uncultured alphaproteobacterium clone } \\
\text { MSB-3ax5 }\end{array}$ & - & + & - & - & - & - \\
\hline $\begin{array}{l}\text { Uncultured Sphingomonadales } \\
\text { HF0500_24B12 }\end{array}$ & + & - & - & + & - & - \\
\hline \multicolumn{7}{|l|}{ Uncultured Bacterium } \\
\hline Bacterium BW3PhG36 & - & + & - & - & - & - \\
\hline Bacterium EB225 & - & - & + & - & - & - \\
\hline
\end{tabular}

Table 2. (continued) List of bacterial species from six stations along South Harbour, Manila Bay, Philippines in August 2012 using 16S rDNA identification. Note: $(-)$ absent, $(+)$ present equivalent to 1 isolate, $\left(^{*}\right)$ reported human pathogen, same colored signs - one isolate has the same percent similarity (considering same length of base pairs) for two bacterial species (continued).

\begin{tabular}{|c|c|c|c|c|c|c|}
\hline \multirow[t]{2}{*}{ Taxa } & \multicolumn{6}{|c|}{ Station } \\
\hline & 1 & 2 & 3 & 4 & 5 & 6 \\
\hline \multicolumn{7}{|l|}{ Uncultured Bacterium (continued) } \\
\hline Uncultured bacterium clone $\mathrm{A} 23$ & - & + & - & - & - & - \\
\hline Uncultured bacterium clone B10 & + & + & - & + & - & - \\
\hline Uncultured bacterium clone BJGMM -1s-92 & + & - & + & - & - & - \\
\hline Uncultured bacterium clone $\mathrm{C} 2 \mathrm{~F}$ & + & - & - & - & - & - \\
\hline Uncultured bacterium clone CK_1C4_50 & - & + & - & - & - & - \\
\hline Uncultured bacterium clone $\mathrm{FA}-\mathrm{F} 1$ & - & - & - & + & - & - \\
\hline Uncultured bacterium clone JSS_4437 & - & - & - & - & + & - \\
\hline Uncultured bacterium clone ncd15a10c1 & - & - & + & - & - & - \\
\hline Uncultured bacterium clone NR16 & + & - & - & - & - & - \\
\hline Uncultured bacterium clone REP5- 30 & + & - & - & - & - & - \\
\hline Uncultured bacterium clone TX2_7M18 & - & - & - & + & - & - \\
\hline Uncultured bacterium gene, clone SC -148 & - & - & - & + & - & - \\
\hline Uncultured organism clone ctg_CGOF223 & - & - & - & + & - & - \\
\hline Uncultured organism clone ctg_NISA074 & - & - & + & ++++ & + & - \\
\hline \multicolumn{7}{|l|}{ Bottom water samples } \\
\hline \multicolumn{7}{|l|}{ Phylum Actinobacteria } \\
\hline Dermacoccaceae bacterium 39 & - & + & - & - & - & - \\
\hline Microbacterium schleiferi strain 2PR54-18 & + & - & - & - & - & - \\
\hline Mycobacterium sp. CNJ823 PL04 & ++ & - & - & - & - & - \\
\hline Mycobacterium mageritense strain 01BRMAR & + & - & - & - & - & - \\
\hline Tetrasphaera japonica strain TX-X7 & + & - & - & - & - & - \\
\hline \multicolumn{7}{|l|}{ Phylum Firmicutes } \\
\hline Bacillus sp. PTK PROLIP 1 & - & - & + & - & - & - \\
\hline Bacillus baekryungensis strain LS218 & - & - & + & - & - & - \\
\hline Virgibacillus salarius strain SA-Vb1 & ++ & - & - & - & - & - \\
\hline \multicolumn{7}{|l|}{ Phylum Proteobacteria } \\
\hline Altererythrobacter sp. JL1452 & - & - & - & - & ++ & - \\
\hline Erytrhobacter sp.1LE255 & - & - & - & - & ++ & - \\
\hline Erythrobacter sp. AS-45 & - & - & + & - & - & - \\
\hline Erythrobacter sp. CAR-8007 & - & - & - & - & + & - \\
\hline Paracoccus sp. YT0095 & - & + & - & - & - & - \\
\hline Rhizobium giardinii strain D30 & + & - & - & - & - & - \\
\hline Rhodobacteraceae bacterium F5 & - & - & + & - & - & - \\
\hline Sphingopxis alaskensis RB2256 & + & - & - & - & - & - \\
\hline Uncultured Aliihoeflea sp. clone $\mathrm{N}-78$ & - & + & - & - & - & - \\
\hline \multicolumn{7}{|l|}{ Uncultured Bacterium } \\
\hline Bacterium EB225 & + & - & - & - & - & - \\
\hline Uncultured bacterium clone $\mathrm{C} 2 \mathrm{~F}$ & - & + & - & - & - & - \\
\hline Uncultured organism clone ctg_CGOF223 & + & - & - & - & - & - \\
\hline Uncultured organism clone ctg_CGOF225 & - & - & - & - & + & - \\
\hline Uncultured bacterium clone LPB-2 & - & - & + & - & - & - \\
\hline
\end{tabular}

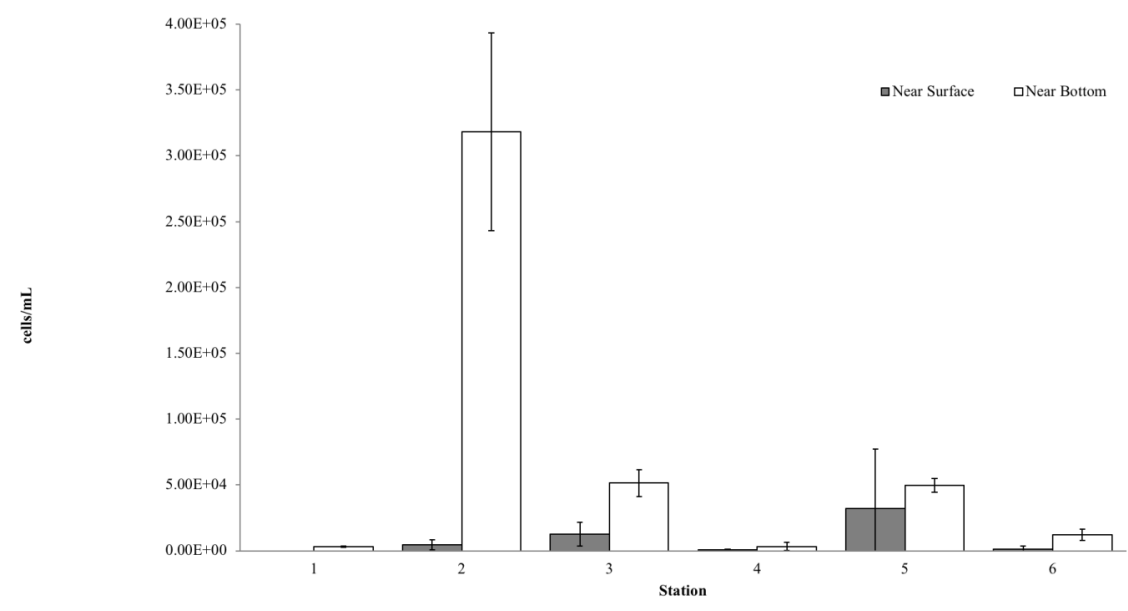

Figure 3. Mean bacterial abundance (average of 3 readings) from surface and bottom waters in South Harbour in July 2012 per station. 
general, higher mean abundance readings were observed in bottom waters than surface waters. Highest mean reading was recorded for station 2 (Pier 13).

Moreover, a total of 93 bacteria were isolated from surface and bottom waters of South Harbour, Manila Bay on August 2012 (Table 2). Sixty-nine (69) of which were from surface waters, while 24 isolates were collected from bottom waters. Sixty-four (64) isolates were representatives of four bacterial phyla: Actinobacteria (22\%), Bacteriodetes (1\%), Firmicutes (12\%), and Proteobacteria (34\%). On the other hand, 31\% (29 isolates) of the isolates were identified as uncultured bacterial clones. Three isolates were identified as reported pathogenic bacteria, namely: Gordonia bronchialis, Kytococcus sedentarius, and Microbacterium oleivorans.

\section{DISCUSSION}

This paper reports for the first time the abundance of potentially HAB forming algae, as well as other phytoplankton and bacterial assemblages in South Harbour, Manila. The phytoplankton assemblages were dominated mostly by diatoms in 2012 (July 6 and August 8) and also in 2013 (April 10 and May 10) (Figure 2). Previous studies by Azanza and Miranda (2001) also showed diatoms were the dominant taxon in Manila Bay in all seasons from 1997 to 1999. Furthermore, the abundance of Skeletonema costatum in July and August 2012, and Chaetoceros spp. in April and May 2013, in South Harbour were observed by Azanza and Miranda (2001) when both species were found to occur in high densities in Manila Bay. Other studies elsewhere, such as in Visakhapatnam Harbour in India, Rao and Mohanchand (1988) found S. costatum as the dominant species. Similarly, Huo and Shu (2005) showed S. costatum to be a cosmopolitan species in the coastal and estuarine areas in China, which could be associated with heavy rainfall (Liu et al. 2005). Five diatom taxa have also been observed dominating in South Harbour during separate sampling activities between 2011 and 2013, which included Rhizosolenia spp., Dytillum spp., and Thalassiosira spp.

The abundance of diatoms in the area may be associated with the high organic and nutrient loading in Manila Bay that could contribute to the increased frequency of microalgal blooms (Jacinto et al. 2006). Thornton and Thake (1998) found out that increasing temperature enhanced aggregation of S. costatum; whereas, certain species of Chaetoceros (e.g., C. gracilis, C. simplex, and C. wighamii) recorded optimal growth at higher temperature and salinity (Mortensen et al. 1988; Araujo and Garcia 2005; Hemalatha et al. 2012). In contrast, S. costatum population in South Harbour declined with increasing surface water temperatures from July to August in 2012 with sea surface temperature from $28^{\circ}-31^{\circ} \mathrm{C}$ respectively and further dropped during the months of April and May in 2013 coinciding with $29^{\circ}-33^{\circ} \mathrm{C}$ sea surface temperatures. These contrasting results may be an indication that other factors were affecting microalgal population growth. Heavy rainfall and tropical storms that flooded metro Manila between the months of June and September in 2012 may have also influenced the decreasing phytoplankton abundance from July to August in the same year, where salinity ranged between 14 psu and 30 psu. Moreover, the obvious increased densities of Chaetoceros spp. that was evident in the succeeding year during the months of April and May, may also indicate salinity-driven aggregation in some species (Araujo and
Garcia 2005) where a higher salinity range was recorded in South Harbour from 30 to 34 psu in April and May 2013.

It is important to note that the abundance of these organisms maybe influenced by a combination of factors e.g., grazing, nutrient loading and physiological aspects of the dominating organisms. Manila Bay is known to be highly eutrophicated, with higher nitrogen concentrations particularly ammonium compounds (Chang et al. 2009), which may be linked with the concurrent microalgal growths including HABs in the area (Azanza et al. 2004). It is suggested that in the case in South Harbour, phytoplankton blooms may have been eutrophication driven, causing phytoplankton like Chaetoceros spp. and S. costatum to proliferate at a higher rate. Potentially harmful algal bloom-causing diatoms (e.g., Chaetoceros spp., Coscinodiscus spp., and Pseudo-nitszchia spp.) and dinoflagellates (e.g., Akashiwo sanguineum, Alexandrium spp., Ceratium furca, C. fusus, Dinophysis caudata, D. miles, Gymnodimium spp., Noctiluca scintillans, Prorocentrum micans, P. rhathymum, and P. sigmoides) were also identified in this study. Certain species have previously been reportedly problematic in some regions causing negative environmental and economic impacts (Mahoney and Steimi 1980; Albright et al. 1993; Kent et al. 1985; Volkman et al. 1999; d'Ippolito et al. 2004; Jessup et al. 2009; Fernandes and Frassao-Santos 2011; Nishikawa et al. 2010; Vale 2011; Tahira and Siddiqui 2012; Trainer et al. 2012).

On the other hand, the majority of bacterial isolates identified belonged to Phylum Proteobacteria, Class Alphaproteobacteria (Table 2). Bacteria from Order Rhodobacterales of this class were reported as the dominant primary surface-colonizers in temperate coastal marine waters (Dang et al. 2008). Three isolates were reported as pathogenic bacteria, namely: Gordonia bronchialis, Kytococcus sedentarius, and Microbacterium oleivorans. G. bronchialis is a human pathogen associated with pulmonary disease that has been isolated in various human tissues (Ivanova et al. 2010). It was assigned a new genus Gordona by Tsukamura (1971) using descriptions from sputum samples from Japanese patients with cavitary pulmonary tuberculosis and/or bronchiectasis and soil samples. K. sedentarius is a species of interest due to its capability to produce oligoketides, a natural antibiotic. It is also considered an opportunistic pathogen that causes valve endocarditis, hemorrhagic pneumonia and pitted keratolysis (Sims et al. 2009). M. oleivorans was proposed as a novel crude-oil degrading Gram-positive bacterium that was isolated from oil storage cavern 126 near Etzel, Germany and previously characterized by Bock et al. (1994) (see Schippers et al. 2005). In 2012, Kim and Lee reported a case of bacteremia in a 4-year old Korean boy caused by the said bacterium.

The presence of potentially harmful algae and pathogenic bacteria along with the increasing vessel traffic in South Harbour would implicate high risks in transporting them into new waters. Results of this study will serve as a baseline for phytoplankton particularly HAB species and marine bacteria in the area. Whether South Harbour serves as the receiver or donor habitat for the identified species may not be concluded from the acquired data; hence, further studies focused on determining critical factors that may contribute to proliferation of phytoplankton and bacterial species, possible risks/negative impacts and potential management schemes should follow. 


\section{ACKNOWLEDGEMENTS}

The authors would like to acknowledge the Department of Science and Technology-Philippine Council for Agriculture, Aquatic and Natural Resources Research and Development (DOST-PCAARRD) for providing financial support for this research through the project "Biotoxin tracking system in ballast water" implemented by the Marine Science Institute, University of the Philippines (UPMSI); the Philippine Coast Guard: Marine Environmental Protection Command (MEPCOM) and Port State Control Manila (PSC) for providing staff and field assistance in boarding international vessels; Philippine Ports Authority (PPA) and the Asian Terminals Incorporated (ATI) for giving permissions in conducting our research in South Harbour Manila Bay. The authors would also like to thank Dr. Azanza's Marine Microalgal Laboratory's staff/personnel for being so considerate and helpful in the analysis of our samples. The authors also wish to acknowledge the support of the ASEAN/India Cooperation Project "Extent of transfer of marine invasive organisms in South/Southeast Asia Region by shipping" led by the National Institute of Oceanography (NIO), Goa, India and the National University of Singapore (NUS).

\section{REFERENCES}

Albright LJ, Yang CZ, Johnson S. 1993. Sub-lethal concentrations of the harmful diatoms Chaetoceros concavicornis and C. concolutus increase mortality rates of penned Pacific salmon. Aquaculture 117:215-225.

Altug G, Gurun S, Cardak M, Ciftci PS, Kalkan S. 2012. The occurrence of pathogenic bacteria in some ship's ballast water from various marine regions to the Sea of Marmara, Turkey. Marine Environmental Research 81:35-42.

Altschul SP, Gish W, Miller W, Myers EW, Lipman DJ. 1990. Basic local alignment search tool. Journal of Molecular Biology 215(3):403-410.

Araujo SC, Garcia VMT. 2005. Growth and biochemical composition of the diatom Chaetoceros cf. wighami Brightwell under different temperature, salinity and carbon dioxide levels. I. Protein, carbohydrates and lipids. Aquaculture 246:405-412.

Azanza RV. 1997. Contributions to the understanding of the bloom dynamics of Pyrodinium bahamense var. compressum; a toxic red tide causative organism. Science Diliman 9(1-2):1-6.

Azanza RV, Miranda LN. 2001. Phytoplankton composition and P. bahamense toxic blooms in Manila Bay, Philippines. Journal of Shellfish Research 20(3):1251-1255.

Azanza RV, Siringan FP, McGlone MLSD, Yñiguez AT, Macalalad NH, Zamora PB, Agustin MB, Matsuoka K. 2004. Horizontal dinoflagellate cyst distribution, sediment characteristics and benthic flux in Manila Bay, Philippines. Phycological Research 52:376-386.

Bock M, Kampfer P, Bosecker K, Dott W. 1994. Isolation and characterization of heterotrophic, aerobic bacteria from oil storage caverns in northern Germany. Applied Microbiology and Biotechnology 42:463-468.

Butron A, Orive E, Madariaga I. 2011. Potential risk of harmful algae transport by ballast waters: the case of Bilbao Harbour. Marine Pollution Bulletin 62:747-757.

Chandrasekera WU, Fernando MAST. 2009. Accidental introduction of alien plankton in the Sri Lankan coastal zone through ballast water of cargo ships. Sri Lanka Journal of Aquatic Sciences 14:87-103.

Chang KH, Amano A, Miller TW, Isobe T, Maneja R, Siringan F, Imai H, Nakano S. 2009. Pollution study in Manila Bay: eutrophication and its impact on plankton community. In: Obayashi Y, Isobe T, Subramanian $\mathrm{A}$, Suzuki $\mathrm{S}$, Tanabe $\mathrm{S}$, editors. Interdisciplinary studies on environmental chemistryenvironmental research in Asia. Tokyo: Terrapub. p. 261-267.

Corrales RA, Reyes M, Martin M. 1995. Notes on the encystment and excystment of Pyrodinium bahamense var. compressum in vitro. In: Lassus P, Arzuk G, Erard-Le Denn E, Gentien P, Marcaillou-Le Baut C, editors. Harmful marine algal blooms. Paris: Lavoisier Science Publ. p. 573-578.

Dang H, Li T, Chen M, Huang G. 2008. Cross-ocean distribution of Rhodobacterales bacteria as primary surface colonizers in temperate coastal marine waters. Applied and Environmental Microbiology 74(1):52-60.

D'Ippolito G, Tucci S, Cutignano A, Romano G, Cimino G, Miralto M, Fontana A. 2004. The role of complex lipids in the synthesis of bioactive aldehydes of the marine diatom Skeletonema costatum. Biochemica et Biophysica Acta 1686:100-107.

Drake LA, Doblin MA, Dobbs FC. 2007. Potential microbial bioinvasions via ships' ballast water, sediment, and biofilm. Marine Pollution Bulletin 55:333-341.

Fernandes LF, Frassao-Santos EK. 2011. Mucilaginous species of Thalassiosira Cleve emend. Hasle (Diatomeae) in South Brazil waters. Acta Botanica Brasilica 25(1):31-42.

Hansen PJ, Miranda L, Azanza R. 2004. Noctiluca scintillans: a dinoflagellate with its own greenhouse. Marine Ecology Progress Series 275:79-87.

Hemalatha A, Panneerselvam K, Manimaran K, Sampathkumar P. 2012. Effect of temperature on the growth of marine diatom, Chaetoceros simplex (Ostenfeld, 1901) with different nitrate:silicate concentrations. Asian Pacific Journal of Tropical Biomedicine Supplement 2(3):S1817-S1821.

Ho AYT, Xu J, Yin K, Yuan X, He L, Jiang Y, Lee JHW, Anderson DM, Harrison PJ. 2008. Seasonal and spatial dynamics of nutrients and phytoplankton biomass in Victoria Harbour and its vicinity before and after sewage abatement. Marine Pollution Bulletin $57: 313-324$.

Huo WY, Shu JJ. 2005. Outbreak of Skeletonema costatum bloom and its relations to environmental factors in Jiaozhou Bay, China. In: WSEAS International Conference on Environment, Ecosystems and Development, Venice, Italy. p. 205-210.

Ivanova N, Sikorski J, Jando M, Lapidus A, Nolan M, Lucas S, Del Rio TG, Tice H, Copeland A, Cheng JF, et al. 2010. Complete genome sequence of Gordonia bronchialf is type strain $\left(3410^{\mathrm{T}}\right)$. Standards in Genomics 2:19-28.

Jacinto GS, Azanza RV, Velasquez IB, Siringan FP. 2006. Manila Bay: environmental challenges and opportunities. In: Wolanski E, editor. The environment in Asia Pacific Harbours. Dordrecht: Springer. p. 309-328.

Jessup DA, Miller MA, Ryan JP, Nevins HM, Kerkering HA, Mekebri A, Crane DB, Johnson TA, Kudela RM. 2009. Mass stranding of marine birds caused by a surfactant-producing red tide. PLoS ONE 4(2):e4550.

Kent ML, Whyte JNC, LaTrace C. 1995. Gill lesions and mortality in seawater pen-reared Atlantic salmon Salmo salar associated with a bloom of Skeletonema cost- 
atum and Thalassiosira species. Disease of Aquatic Organisms 22:77-81.

Kim BH, Lee MK. 2012. A case of bacteremia due to Microbacterium oleivorans identified by $16 \mathrm{~S}$ rRNA sequencing analysis. Korean Journal of Clinical Microbiology 15(3):110-113.

Liu DY, Sun J, Zou JZ, Zhang J. 2005. Phytoplankton succession during a red tide of Skeletonema costatum in Jiaozhou Bay of China. Marine Pollution Bulletin 50:91-94.

Mahoney JB, Steimi FW. 1980. Possible association of fishing gear clogging with a diatom bloom in the middle Atlantic Bight. Bulletin of the New Jersey Academy of Science 25:18-21.

Marie D, Vaulot D, Partensky F. 1996. Application of the novel nucleic acid dyes YOYO-1-YO-PRO-1 and PicoGreen analysis of marine prokaryotes. Applied Environmental Microbiology 62:1649-1655.

Mortensen SH, Børsheim KY, Rainuzzo JR, Knutsen G. 1988. Fatty acid and elemental composition of the marine diatom Chaetoceros gracilis Schütt. Effects of silicate deprivation, temperature and light intensity. Journal of Experimental Marine Biology and Ecology 122:173-185.

Nishikawa T, Tarutani K, Yamamoto T. 2010. Nitrate and phosphate uptake kinetics of the harmful diatom Coscinodiscus wailesii, a causative organism in the bleaching of aquacultured Porphyra thalli. Harmful Algae 9:563-567.

Philippine Ports Authority. 2015. Ports Services Handbook: South Harbour. Manila: Philippine Ports Authority.

Rao UM, Mohanchand V. 1988. Water quality characteristics and phytoplankton of polluted Visakhapantanam Harbour. Marine Environmental Research 25:23-43.

Schippers A, Bosecker K, Sproer C, Schumann P. 2005. Microbacterium oleivorans sp. nov. and Microbacterium hydrocarbonoxydans sp. nov., novel crude-oil-degrading Gram-positive bacteria. International Journal of Systematic and Evolutionary Microbiology 55:655-660.

Sims D, Brettin T, Detter JC, Han C, Lapidus A, Copeland A, Del Rio TG, Nolan M, Chen F, Lucas S, et al. 2009. Complete genome sequence of Kytococcus sedentarius type strain $\left(541^{\mathrm{T}}\right)$. Standards in Genomic Science 1:12-20.
Smayda T. 2007. Reflections on the ballast water dispersalharmful algal paradigm. Harmful Algae 6:601-622.

Tahira N, Siddiqui PJA. 2012. Taxonomy of potentially harmful diatom Coscinodiscus wailesii Gran et Angst (Coscinodiscales, Bacillariophyta) from Pakistan waters. Journal of Algal Biomass Utilization 3(1):28-31.

Thornton DCO, Thake B. 1998. Effect of temperature on the aggregation of Skeletonema costatum (Bacillariophyceae) and the implication for carbon flux in coastal waters. Marine Ecology Progress Series 174:223-231.

Tomas CR, editor. 1997. Identifying marine phytoplankton. San Diego: Academic Press.

Trainer VL, Bates SS, Lundholm N, Thessen AE, Cochlan WP, Adams NG, Trick CG. 2012. Pseudo-nitzschia physiological ecology, phylogeny, toxicity, monitoring and impacts on ecosystem health. Harmful Algae 14:271-300.

Tsukamura M. 1971. Proposal of a new genus, Gordona, for slightly acid-fast organisms occurring in sputa of patients with pulmonary disease and in soil. Journal of General Microbiology 68:15-26.

Vale P. 2011. Hydrolysis of hydroxibenzoate saxitoxin analogues originating from Gymnodinium catenatum. Food Chemistry 125:1160-1165.

Varela M, Prego R. 2003. Hydrography and phytoplankton in an isolated and non-pristine area: the A Coruña Harbour (NW Spain). Acta Oecologica 24(2):113-124.

Volkman JK, Rijpstra WIC, de Leeuw JW, Mansour MP, Jackson AE, Blackburn SI. 1999. Sterols of four dinoflagellates from genus Prorocentrum. Phytochemistry 52:659-668.

Webber MK, Webber DF, Ranston ER, Dunbar FN, Simmonds RMA. 2003. Changes in water quality and plankton of Kingston Harbour, Jamaica, after 20 years of continued eutrophication. Bulletin of Marine Science 73(2):361-378.

Yamaji I. 1984. Illustrations of the marine plankton of Japan. $3^{\text {rd }}$ ed. Tokyo: Hoikusha Publishing Co.

Zamora-Ley IM, Gardinali PR, Jochem FJ. 2006. Assessing the effects of Irgarol 1051 on marine phytoplankton populations in Key Largo Harbor, Florida. Marine Pollution Bulletin 52:935-941. 
